\title{
Infusion pumps and red blood cell damage in transfusion therapy: an integrative revision of the academic literature ${ }^{1}$
}

\author{
Ana Maria Miranda Martins Wilson² \\ Maria Angélica Sorgini Peterlini ${ }^{3}$ \\ Mavilde da Luz Gonçalves Pedreira ${ }^{3}$
}

\begin{abstract}
Objectives: to obtain information from scientific literature concerning infusion pumps used in administering erythrocyte (red blood cells) and to evaluate the implications in the practical use of this equipment by nurses when conducting transfusions. Method: an integrative revision of the following scientific databases: Pubmed/Medline, Scopus, the Virtual Library for Health, SciELO, Web of Science and Cochrane. The following descriptors were used: "infusion pumps", "blood transfusion", "transfused erythrocyte" and "hemolyis". There were no restrictions on the scope of the initial data and it was finalized in December 2014. 17 articles were identified in accordance with the inclusion and exclusion criteria. Results: all of the publications included in the studies were experimental in vitro and covered the use of infusion pumps in transfusion therapy. A summary of the data was presented in a synoptic chart and an analysis of it generated the following categories: cellular damage and the infusion mechanism. Conclusion: infusion pumps can be harmful to erythrocytes based on the infusion mechanism that is used, as the linear peristaltic pump is more likely to cause hemolysis. Cellular damage is related to the plasmatic liberation of markers that largely dominate free hemoglobin and potassium. We reiterate the need for further research and technological investments to guide the development of protocols that promote safe practices and that can contribute to future clinical studies.
\end{abstract}

Descriptors: Nursing; Infusion Pumps; Erythrocytes; Hemolysis.

\footnotetext{
1 Paper extracted from "Marcadores de hemólise de concentrados de hemácias administrados por bombas de infusão peristálticas lineares", presented to Escola Paulista de Enfermagem, Universidade Federal de São Paulo, São Paulo, SP, Brazil. Supported by Fundação de Amparo à Pesquisa do Estado de São Paulo, FAPESP, process \# 2012/25284-9 and by Coordenação de Aperfeiçoamento de Pessoal de Nível Superior (CAPES), Brazil.

2 MSc, RN, Escola de Enfermagem, Universidade de São Paulo, São Paulo, SP, Brazil.

${ }^{3}$ PhD, Associate Professor, Escola Paulista de Enfermagem, Universidade Federal de São Paulo, São Paulo, SP, Brazil.
}

\section{How to cite this article}

Wilson AMMM, Peterlini MAS, Pedreira MLG. Infusion pumps and red blood cell damage in transfusion therapy: an integrative revision of the academic literature. Rev. Latino-Am. Enfermagem. 2016;24:e2763. [Access $\mathrm{f}_{\text {month }}$; Available in: $\left.\right|_{\text {URL }}$. DOI: http://dx.doi.org/10.1590/1518-8345.1155.2763. day year 


\section{Introduction}

Blood transfusion is a therapeutic technology that is commonly used in clinical practices in many different health establishments. Approximately 85 million blood transfusions are done annually in the world, with 15 million of them being carried just in the United States ${ }^{(1)}$. In Brazil in 2014 3,127,957 transfusions were carried out, in which concentrated erythrocytes $(\mathrm{CH})$ were the blood components most used, covering $57.98 \%$ of all transfusions conducted in outpatient units and hospitals in the country ${ }^{(2)}$.

An indication for a $\mathrm{CH}$ transfusion is both clinical and laboratorial which is based on hemoglobin and hematocrit levels as well as any signs and symptoms presented by the patient ${ }^{(1,3)}$.

The implementation of transfusion therapy requires the use of an integrated multidisciplinary team where the following occurs: obtaining blood donors, collection, processing, quality control, distribution, the therapy is prescribed for someone, the transfusion takes place and monitoring the clinical responses ${ }^{(3-4)}$. The role of nurses is fundamental in this process according to the Nursing Federal Council Resolution (COFEN) no 306/2006 which provides directives on the procedures to be used by nurses in hemotherapy. Nurses are professionally qualified to plan, execute, coordinate, supervise and watch patients during their transfusion therapy ${ }^{(5)}$.

In relation to the administration of blood components, nurses are required to use infusion devices that are on the market that present differences concerning: control methods for quality, price, presentation and recommendation of use. The national practice for transfusions involves the use of blood transfusion products that work through the use of gravity with a manual flux control system ${ }^{(4,6)}$.

The infusion pumps (BI) are devices that regulate the flux of liquid administered under positive pressure to the patient. They are used in intravenous therapy in different areas of health care ${ }^{(7-8)}$. Currently BIs are gradually being introduced into the market to be used in blood transfusions.

With reference to flux control, the BIs can be classified as: volumetric infusion pumps, Flow meters and syringe pumps. Volumetric equipment is a type of device that controls the liquid to be infused in volume by unit of time through programming the flow done by the operator. This then controls the syringe pumps. Flow meters or drips work through permitting flows and are also controlled by an operator. However the control of the infused volume is carried out through the counting of drips per unit of time using an electronic sensor. Syringes pumps are instruments in which the volume administered to the patient is stored through the use of one or more syringes which is pushed by a movable piston controlled by equipment. The operator can select the flow rate and can indicate volumes through units of time on the equipment. Barring the BIs syringe pumps, the other devices essentially work through the use of peristaltic mechanisms and cassettes ${ }^{(7-8)}$.

The peristaltic mechanism permits the infusion of liquid through forcefully pushing a part of it from the equipment through which the liquid passes. This can be done through two methods: the peristaltic linear method or the rotatory method. The two methods are different in that one works through the use of wave movement and the other works based on compression on the linear plaques or gyrating rollers respectively. This results in pushing the liquid from the bottle that has the solution to be infused in the circulatory vein network in the patient ${ }^{(7-8)}$.

The cassette mechanism involves infusion through the use of pistons. Such devices have cassettes in side of them that are generally inserted into the center of the equipment. The pistons, upon being actioned, move in and out of the cylinders that are contained in the cassettes. The internal movement pushes the liquid in the direction of the patient, whilst the external movement drains the liquid from the bottle in order to refill the cassette. Additionally there can be diaphragm mounted on the movable pistons inserted in the cassettes. The engine transmits a movement to the pistons that move in and out of the bottles, compressing the siliconized, diaphragmatic membrane permitting it to be filled or to release the liquid. When the pistons go into the cylinders, the liquid is pushed in the direction of the patient and when the pistons move out, the liquid is sucked up from the container that has it, allowing the cassettes bottles to be refilled(7-8).

Although there are innumerable advantages in relation to the safety of the patient through the use of BI in intravenous therapy such as the alarms that it has, the control of the infused volume and providing the adequate time for the liquid to be administered, there is still some uncertainty on their use in transfusion therapy due to the effects of the infusion mechanism on the erythrocytes which may result in hemolysis ${ }^{(9-10)}$.

Patients that are transfused with erythrocyte hemolysate, aside from receiving low levels of functional hemoglobin, can be subject to deleterious effects to the organisms through the presence of freed biomarkers when hemolysis occurs(9-10). With consideration for the above, the guiding question for this study was: If one transfuses erythrocytes using BI, will this result in cellular damage and hemolysis? 


\section{Objectives}

To obtain information from scientific literature concerning the effects of infusion pumps used in administering erythrocyte (red blood cells) and to evaluate the implications in the practical use of this equipment by nurses when conducting transfusions.

\section{Material and method}

We undertook an integrative revision of the relevant literature. We collected data from secondary sources based on a list that we had sourced out. We then analyzed the data obtained in a systemized manner.

The study had six steps: 1) An identification of the theme and a selection of the theory or questions for the research, 2) establishing inclusion and exclusion criteria for the study, as well as conducting searches in the literature, 3 ) defining the information to be extracted from the research that was selected, 4) categorization and evaluation of the included studies, 5) interpreting the results and 6) summarizing the knowledge obtained (11-13).

This research method brings scientific rigor to clinical practices. This permits the inclusion of different types of studies which allows for the following: the maximization of research, critical evaluation and the summarization of evidence that is obtained based on the theme ${ }^{(11-13)}$.

In order to select the articles, we used the following portals and databases: U.S. National Library of Medicine
(PUBMED), Virtual Library for Health (BVS), SciELO, The Cochrane Library (Cochrane), SCOPUS and ISI Web of Science. When using the SciELO database, the descriptors were researched using the basic (not advanced) research field.

In the Science of Health (DECS) and Medical Subject Headings Section (MESH) we used the following descriptors in response to the research question: "infusion pumps", "blood transfusion", "erythrocyte transfusion" and "hemolysis". In our searches we used the words AND and OR.

Our research covered all of the articles published up until the 31 December 2014. The inclusion criteria for the publications were the following: 1) articles published in Portuguese, English and Spanish; 2) complete articles that covered the use of BIs in transfusion therapy; 3 ) any of relevant study. The exclusion criteria was: 1) Opinions from specialists, chapters from books, summaries of journals, patents and editorials, 2) articles that described cellular damage that occurs when using extracorporeal circulation devices and those which provide circulatory assistance with oxygen for extracorporeal membranes (ECMO).

The strategy used to find the articles was modified based on each the database due to the different ways to access each of them. As a guide, we used the research question and the inclusion criteria that had been previously defined. Figure 1 shows the strategy used for the searches done in the Pubmed database. This strategy was used in analyzing the other databases.

\begin{tabular}{|c|c|c|}
\hline Search Number & Descriptors & Boolean Operator \\
\hline$\# 1$ & $\begin{array}{c}\text { "Blood transfusion" [MeSH Terms] } \\
\text { "Erytrhocyte transfusion" [MeSH Terms] }\end{array}$ & OR \\
\hline$\# 2$ & $\begin{array}{c}\text { "Infusion pumps" [MeSH Terms] } \\
\text { "Hemolysis" [MeSH Terms] }\end{array}$ \\
\hline$\# 3$ & "Infusion pumps" [MeSH Terms] AND \#1 & AND \\
\hline$\# 4$ & $\# 1$ AND \#2 & AND \\
\hline$\# 5$ & \#2 OR \#3 \\
\hline
\end{tabular}

Figure 1 - Search Strategy in the Pubmed database- Sao Paulo, 2014

\section{The Procedures for collecting the data}

Initially we looked at the title and the summary of the studies to check that they met the inclusion criteria. The next step was to analyze the complete article that was selected. We needed to see whether the study was pertinent to our study. The publications that did not have the complete text were solicited through the comut/SCAD. Data collection forms were designed by the researchers and were adapted to the objectives of the research, having the following items: identification of original article, methodological characteristics, an evaluation of the methodological rigor used, interventions and the main results found.

The results were presented in a descriptive way permitting anyone to evaluate the applicability of our integrative revision. It would also help them in making decisions in clinical practices related to transfusions and it would show any knowledge gaps. This could help in developing and enhancing future research. 


\section{Procedures for analyzing the data}

From the six databases included in the study, we managed to obtain a total of 566 articles. Of these, 511 fell into our inclusion criteria and our proposed objectives, ending in 55 articles. From this total, 38 were taken out as they were repeats from the databases, which left 17 articles (figure 2).
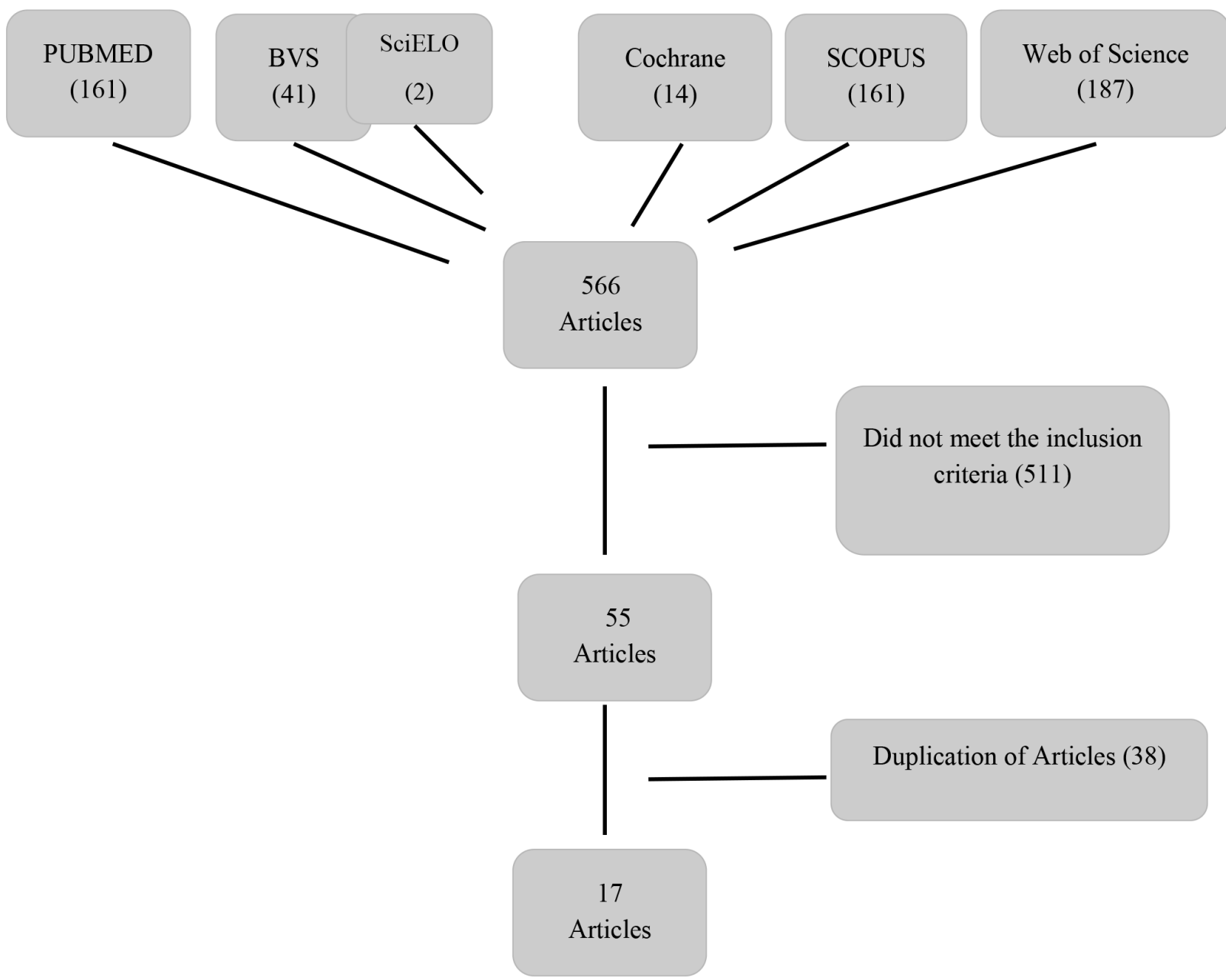

Figure 2 - Flow chart of selection of the articles for the database

All of the studies that were included were experimental designs in vitro. No classification of the levels of the evidence was carried out as they were considered to be pre-clinical studies.

Further on in the research, the studies were analyzed and grouped based on their similar content with two categories to be analyzed: the mechanism of the $\mathrm{BI}$ and the cellular damage.

The presentation of the results from the data that was obtained, was presented in a summary chart which had the following information: information on the authors, the objective of the study, type of study, results, conclusion and the implications in the practices of transfusions done by nurses. This last element had relevant points that were summarized from each article that we analyzed that covered the use of infusion pumps in transfusions done by nurses. It was noted that in some places the aforementioned devices were used in blood transfusions.

\section{Results}

Out of the 17 articles that we found, the majority were in English being: 15 (82\%), 5.9\% were in Spanish and $5.9 \%$ were in Portuguese. With reference to the where the studies had been conducted, 10 (58.9\%) of them had been produced in the United States, one (5.9\%) in England and the remaining six (35.2\%) were produced in the following countries: Brazil, Spain, Australia, Denmark, Holland and Switzerland. Amongst the selected studies, the oldest was produced in 1981 and the most recent in 2011 .

In relation to the design of the 17 studies selected, all of them were experimental having simulations of the procedures in laboratories. With reference to the listed categories corresponding to the infusion mechanism, we analyzed the peculiarities in relation to blood transfusions and the chances of cellular damage due to the mechanical force of the equipment. In the cellular 
damage category, we grouped together related variables to the blood components and cellular damaged markers.
Figure 3 is a presentation of a summary of the studies identified and included in the present integrative revision and our principal results.

\begin{tabular}{|c|c|c|c|c|c|}
\hline $\begin{array}{c}\text { Authors/Place/ } \\
\text { Year }\end{array}$ & Objective & $\begin{array}{l}\text { Type of } \\
\text { Design } \\
\text { Study }\end{array}$ & Sample and Interventions & $\begin{array}{l}\text { Results and } \\
\text { Conclusion }\end{array}$ & $\begin{array}{l}\text { Implications in } \\
\text { the practice of } \\
\text { transfusions for } \\
\text { nursing }\end{array}$ \\
\hline $\begin{array}{l}\text { Wilcox GJ, } \\
\text { Barnes A, } \\
\text { Modanlou H. } \\
\text { California, } \\
\text { EUA,1980 }\end{array}$ & $\begin{array}{l}\text { Evaluate } \\
\text { hemolysis in } \\
\text { the syringe } \\
\text { infusion system } \\
\text { and catheter } \\
\text { needle }\left(25 \mathrm{G}^{*}\right) \text {, } \\
\text { according to } \\
\text { the flux and } \\
\text { storage. }\end{array}$ & $\begin{array}{l}\text { Experi- } \\
\text { mental } \\
\text { study } \\
\text { controlled } \\
\text { in vitro }\end{array}$ & $\begin{array}{l}1617 \text { unit of } \mathrm{CH}^{+} \text {in rates of } \\
15 \mathrm{ml}^{ \pm} \text {. } \\
\text { - Speed of infusion: } 70 ; 20.5 \\
\text { and } 10.6 \mathrm{~mL} / \mathrm{h}^{\S} \\
\text { - Storage period } 2 \text { to } 9 \text { days } \\
\text { - } \quad \text { Variables of outcome: } \mathrm{Hb}^{\prime} \\
\text { Ifree and potassium. }\end{array}$ & $\begin{array}{l}\text { Significant hemolysis } \\
\text { in units with } 9 \text { days } \\
\text { of collection in a } \\
\text { solution of CPDA-1 } \\
\text { and with an infusion } \\
\text { speed of } 10.6 \mathrm{ml} / \mathrm{h}^{\S} \text {. }\end{array}$ & $\begin{array}{l}\text { System of infu- } \\
\text { sion usually used } \\
\text { in neonatology and } \\
\text { pediatrics. Focused } \\
\text { selection of } \mathrm{CH} \text { lower } \\
\text { deadline for storage } \\
\text { in order to prevent } \\
\text { hemolysis. }\end{array}$ \\
\hline $\begin{array}{l}\text { Herrera AJ, } \\
\text { Corless J. } \\
\text { Baltimore, } \\
\text { EUA,1981(15) }\end{array}$ & $\begin{array}{l}\text { To investigate } \\
\text { hemolysis in } \\
\mathrm{BI}^{* *} \text { from } \\
\text { syringes, at } \\
\text { different cath- } \\
\text { eter gauages } \\
\text { and flux. }\end{array}$ & $\begin{array}{l}\text { Experi- } \\
\text { mental } \\
\text { study } \\
\text { controlled } \\
\text { in vitro }\end{array}$ & $\begin{array}{l}36 \text { units of } \mathrm{ST}^{++} \text {and } 24 \mathrm{CH} \text {, } \\
\text { both with } 24 \text { hours of collec- } \\
\text { tions. } \\
\text { Speeds: } 20.50 \text { and } 100 \mathrm{~mL} / \mathrm{h} \\
\text { in the different catheter } \\
\text { gauages connected to a final } \\
\text { infusion line. } 24 \mathrm{CH} \text { evalu- } \\
\text { ated only in relation to flux at } \\
20 \text { and } 50 \mathrm{~mL} / \mathrm{h} \text {. } \\
\text { Variables of outcome: } \mathrm{Hb} \\
\text { free. }\end{array}$ & $\begin{array}{l}\text { Hemolysis was not } \\
\text { found amongst the } \\
\text { control and ex- } \\
\text { perimental samples, } \\
\text { even with high flux } \\
\text { and low catheter } \\
\text { gauge for hemolysis } \\
\text { results. }\end{array}$ & $\begin{array}{l}\text { System of infusion } \\
\text { evaluated as one } \\
\text { system, covering the } \\
\text { following variables: } \\
\text { catheter, flux and } \\
\text { equipment. The im- } \\
\text { portance of isolated } \\
\text { evaluation for every } \\
\text { variable when imple- } \\
\text { menting the therapy. }\end{array}$ \\
\hline $\begin{array}{c}\text { Gibson JS, Leff } \\
\text { RD Roberts, } \\
\text { RJ lowa, EUA, } \\
1984^{(16)}\end{array}$ & $\begin{array}{l}\text { To evaluate } \\
\text { erythrocytes } \\
\text { damage in the } \\
\text { Bls through } \\
\text { the use of } \\
\text { the peristaltic } \\
\text { linear system } \\
\text { for syringe and } \\
\text { diaphragmatic } \\
\text { pumps. }\end{array}$ & $\begin{array}{l}\text { Ex- } \\
\text { perimental } \\
\text { study } \\
\text { controlled } \\
\text { in vitro }\end{array}$ & $\begin{array}{l}\text { - } 144 \text { experimental analysis of } \\
\text { ST and } \mathrm{CH} \text { with } 2 \text { to } 3 \text { days of } \\
\text { collection. } \\
\text { Speeds of infusion: } 5 \mathrm{~mL} / \mathrm{h} \text { e } 50 \\
\mathrm{~mL} / \mathrm{h} \text {. The blood components } \\
\text { were left in room temperature for } \\
\text { two hours before the experiment. } \\
\text { Liquid from the bags was col- } \\
\text { lected from the controlled study. } \\
\text { Variables of outcome: Hb free } \\
\text { and level of hemolysis. }\end{array}$ & $\begin{array}{l}\text { BI linear with greater } \\
\text { level of hemolysis. } \\
\text { Greater hemolysis in flux } \\
\text { of } 5 \mathrm{~mL} / \mathrm{h} \text { in ST and } 50 \\
\mathrm{~mL} / \mathrm{h} \text { in } \mathrm{CH} \text {. Mechanism } \\
\text { of diaphragmatic cas- } \\
\text { sette safe for ST and B } \\
\text { for syringe pumps. Safe } \\
\text { in all scenarios. }\end{array}$ & $\begin{array}{l}\text { Attention to the } \\
\text { prescribed blood compo- } \\
\text { nents, the equipment } \\
\text { mechanism that is } \\
\text { available and the speed } \\
\text { of the infusion to prevent } \\
\text { haemolytic effects. }\end{array}$ \\
\hline $\begin{array}{l}\text { Veerman MK, } \\
\text { Leff RD, Rob- } \\
\text { erts RJ. I lowa, } \\
\text { EUA, 1985(17) }\end{array}$ & $\begin{array}{l}\text { Evaluate } \\
\text { hemolysis in } \mathrm{BI} \\
\text { using volumetric } \\
\text { infusion pumps } \\
\text { with the cassette } \\
\text { mechanism. }\end{array}$ & $\begin{array}{l}\text { Ex- } \\
\text { perimental } \\
\text { study } \\
\text { controlled } \\
\text { in vitro }\end{array}$ & $\begin{array}{l}\text { - } \quad \text { BI cassette mechanism used. } \\
\text { CH and ST with } 2 \text { to } 3 \text { days of } \\
\text { collection, in solutions of CPDA-1 } \\
\text { in } 5 \text { fluxes. } \\
\text { - Total of } 20 \text { experimental analysis. } \\
\text { Speeds of infusion evaluated: } 5 \text {, } \\
\text { 10, } 25,50 \text { and } 100 \mathrm{~mL} / \mathrm{h} \text {. } \\
\text { - Catheter gauge: } 22 \mathrm{G} . \\
\text { Variables of outcome: } \mathrm{Hb} \text { free } \\
\text { and percentage of hemolysis. }\end{array}$ & $\begin{array}{l}\text { Haemolytic results found } \\
\text { however below the rec- } \\
\text { ommendation for the last } \\
\text { day }\left(35^{\circ}\right) \text { of the collec- } \\
\text { tion. The conclusion was } \\
\text { the hemolysis presented } \\
\text { was insignificant. }\end{array}$ & $\begin{array}{l}\text { BI cassette mechanism } \\
\text { considered safe by the } \\
\text { authors, with small vari- } \\
\text { ations in the standards } \\
\text { of control of quality. }\end{array}$ \\
\hline $\begin{array}{l}\text { Thompson HW, } \\
\text { Lasky LC, } \\
\text { Polesky HF. } \\
\text { Minnesota, } \\
\text { EUA, 1986 }{ }^{(18)}\end{array}$ & $\begin{array}{l}\text { Evaluate } \\
\text { hemolysis in BI } \\
\text { using volumetric } \\
\text { infusion pumps } \\
\text { with cassette } \\
\text { mechanism. }\end{array}$ & $\begin{array}{l}\text { Ex- } \\
\text { perimental } \\
\text { study } \\
\text { controlled } \\
\text { in vitro }\end{array}$ & $\begin{array}{l}10 \text { unit of } \mathrm{CH} \text { stored in CPDA-1 } \\
\text { for } 35 \text { days. } \\
\text { Flux evaluated was from } 300 \text { to } \\
850 \mathrm{~mL} / \mathrm{h} \\
\text { The samples from the bag were } \\
\text { obtained through suction using a } \\
\text { needle gauge at } 19 \mathrm{G} \\
\text { Variables of outcome: Hb free, } \\
\text { osmotic fragility and potassium. }\end{array}$ & $\begin{array}{l}\text { Haemolytic results not } \\
\text { statistically significant. } \\
\mathrm{Hb} \text { free increased in } \\
\text { both of the Bls, associ- } \\
\text { ated with high flux and } \\
\text { deadline for storage. }\end{array}$ & $\begin{array}{l}\text { Although the } \\
\text { hemolysis was not } \\
\text { significant, empha- } \\
\text { sis was placed on } \\
\text { a critical evalua- } \\
\text { tion and the period } \\
\text { of storage of the } \\
\text { blood components } \\
\text { for implementing } \\
\text { the prescribed } \\
\text { therapy. }\end{array}$ \\
\hline
\end{tabular}




\begin{tabular}{|c|c|c|c|c|c|}
\hline $\begin{array}{c}\text { Authors/Placel } \\
\text { Year }\end{array}$ & Objective & $\begin{array}{l}\text { Type of } \\
\text { Design } \\
\text { Study }\end{array}$ & Sample and Interventions & $\begin{array}{l}\text { Results and } \\
\text { Conclusion }\end{array}$ & $\begin{array}{l}\text { Implications in } \\
\text { the practice of } \\
\text { transfusions for } \\
\text { nursing }\end{array}$ \\
\hline $\begin{array}{l}\text { Angel JA, } \\
\text { O'BrienWF, } \\
\text { Knuppl RA, } \\
\text { Warren MB, } \\
\text { Leparc GF } \\
\text { Florida, EUA, } \\
1987^{(19)}\end{array}$ & $\begin{array}{l}\text { To determine the } \\
\text { hemolysis in } \mathrm{CH} \\
\text { transfused in an } \\
\text { intrauterine way, } \\
\text { evaluating the } \\
\text { rate of infusion, } \\
\text { the catheter } \\
\text { gauge and the BI. }\end{array}$ & $\begin{array}{l}\text { Ex- } \\
\text { perimental } \\
\text { study } \\
\text { controlled } \\
\text { in vitro }\end{array}$ & $\begin{array}{l}\text { - Two rates at } 100 \mathrm{ml} \mathrm{CH} \text { in a solu- } \\
\text { tion of CPDA-1. } \\
\text { - Storage: } 7 \text { days, radiated to } 2,500 \\
\text { rads }{ }^{ \pm} \text {. } \\
\text { - Flux of } 60-360 \mathrm{ml} / \mathrm{h} \text {, infused by } \\
\text { spinal needles gauged at } 20 \text { or } 22 \\
\text { G, from } 8 \text { to } 9 \mathrm{~cm} \text { (length). } \\
\text { Variables outcomes: number of } \\
\text { erythrocytes, hematocrit and } \mathrm{Hb} \\
\text { free. }\end{array}$ & $\begin{array}{l}\text { Level of hemolysis } \\
\text { greater at lower needle } \\
\text { gauges and at higher } \\
\text { values of hematocrit } \\
\text { from the bag. Flows, not } \\
\text { resulting in significant } \\
\text { hemolysis. }\end{array}$ & $\begin{array}{l}\text { The intrauterine transfu- } \\
\text { sion is a procedure } \\
\text { used for fetuses at } \\
\text { high risk. In order to } \\
\text { prevent hemolysis the } \\
\text { recommendations is } \\
\text { for fast infusions at low } \\
\text { hematocrit values and } \\
\text { high needle gauge. }\end{array}$ \\
\hline $\begin{array}{l}\text { Gurdak RG, An- } \\
\text { derson G, Min- } \\
\text { stz PD.Virginia, } \\
\text { EUA, } 1988^{(20)}\end{array}$ & $\begin{array}{l}\text { To detemine } \\
\text { hemolysis in } \mathrm{BI} \\
\text { linear peristaltic } \\
\text { pump. }\end{array}$ & $\begin{array}{l}\text { Ex- } \\
\text { perimental } \\
\text { study } \\
\text { controlled } \\
\text { in vitro }\end{array}$ & 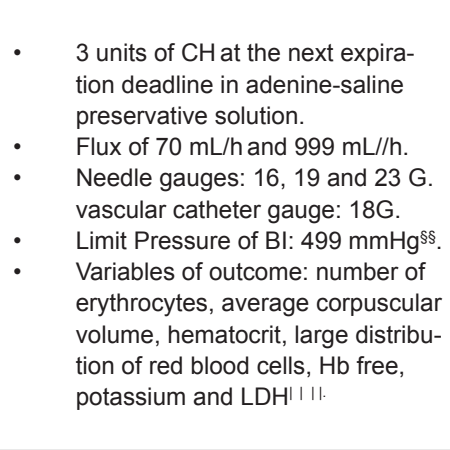 & $\begin{array}{l}\mathrm{Hb} \text { free with an increase } \\
\text { in the quantity being } \\
18 \mathrm{G} \text { and } 70 \mathrm{~mL} / \mathrm{h} \text {, } \\
\text { without statistical } \\
\text { significance. Hemolysis } \\
\text { was found, however } \\
\text { not clinically significant } \\
\text { (least than } 0.8 \% \text { ). }\end{array}$ & $\begin{array}{l}\text { A simulation of the } \\
\text { worse scenario for } \\
\text { storage, where } \mathrm{BI} \text { is } \\
\text { considered safe based } \\
\text { on the evaluation of } \\
\text { the level of clinical } \\
\text { hemolysis significance, } \\
\text { in spite of the significant } \\
\text { alterations of the values } \\
\text { in relation to the control } \\
\text { samples. Variation of the } \\
\text { infusion pressure of the } \\
\text { equipment in high rates } \\
\text { of infusion. }\end{array}$ \\
\hline $\begin{array}{l}\text { Denison M, Bell } \\
\text { PU, Schul- } \\
\text { dreichh R, } \\
\text { Chaudri MA. } \\
\text { Melbourne, } \\
\text { Australia, } \\
\text { 1991(21) }\end{array}$ & $\begin{array}{l}\text { To evaluate } \\
\text { hemolysis in } \\
\text { the BI using the } \\
\text { following mecha- } \\
\text { nism s: } \\
\text { 1-diaphragmatic; } \\
\text { 2-Linear } \\
\text { peristaltic pump; } \\
\text { 3-syringe pump } \\
\text { 4- diaphragmatic } \\
\text { with flux of } 100 \\
\mathrm{~mL} / \mathrm{h} \text {. }\end{array}$ & $\begin{array}{l}\text { Ex- } \\
\text { perimental } \\
\text { study } \\
\text { controlled } \\
\text { in vitro }\end{array}$ & $\begin{array}{l}\text { - } 4 \text { units of } \mathrm{CH} \text { with storage of least } \\
\text { than } 24 \text { hours. } \\
\text { Experiment carried out based on } \\
\text { controlling gravity. } \\
\text { Variables of outcome: } \mathrm{Hb} \text { free } \\
\text { and hemoglobin total. }\end{array}$ & $\begin{array}{l}\mathrm{Hb} \text { free in Bl of syringe } \\
\text { pumps and diaphrag- } \\
\text { matic pumps modi- } \\
\text { fied, without statistical } \\
\text { significance. Significant } \\
\text { cellular damage after } \\
\text { infusion by BI linear } \\
\text { pumps. }\end{array}$ & $\begin{array}{l}\text { Mechanism of } \\
\text { diaphragmatic cassette } \\
\text { considered safer for } \\
\text { transfusions. Cellular } \\
\text { damage was present in } \\
\text { manual filling syringe } \\
\text { refills through pressure } \\
\text { during suction. Hemoly- } \\
\text { sis in BI linear peristaltic } \\
\text { pumps. }\end{array}$ \\
\hline $\begin{array}{l}\text { Strayer AH, } \\
\text { Henry DW, } \\
\text { Erenberg A, Leff } \\
\text { RD Kansas, } \\
\text { EUA, 1991(22) }\end{array}$ & $\begin{array}{l}\text { To determine } \\
\text { the action of the } \\
\text { cassette BI in } \\
\text { relation to the } \\
\text { integrity of the } \\
\text { red blood cells. }\end{array}$ & $\begin{array}{l}\text { Ex- } \\
\text { perimental } \\
\text { controlled } \\
\text { study in } \\
\text { vitro }\end{array}$ & $\begin{array}{ll}\text { - } & 3 \text { units of } \mathrm{CH}^{\dagger} \text { and } \mathrm{ST} \text {, in solution } \\
\text { - } & \text { of } \mathrm{CPDA}-1 . \\
& \text { Erythrocyte with } 35 \text { to } 36 \text { days of } \\
\text { collection. } \\
\text { - } & \text { Flux: } 250 \mathrm{~mL} / \mathrm{h} . \\
\text { - } & \text { Needle/catheter gauge: } 18 \mathrm{G} . \\
& \text { Variables of outcome: } \mathrm{Hb} \text { free. }\end{array}$ & $\begin{array}{l}\text { There was no significant } \\
\text { increase in } \mathrm{Hb} \text { free in the } \\
\text { two blood components } \\
\text { groups. The cassette BI } \\
\text { did not affect the integ- } \\
\text { rity of the erythrocytes. }\end{array}$ & $\begin{array}{l}\text { Bl considered safe for } \\
\text { transfusion for both } \\
\text { blood components with } \\
\text { flux that simulates the } \\
\text { scenario of fast transfu- } \\
\text { sion. }\end{array}$ \\
\hline $\begin{array}{l}\text { Burch KJ, } \\
\text { Fhelps SJ, Con- } \\
\text { stance TD, } \\
\text { Tennessee, } \\
\text { EUA, 1991 }\end{array}$ & $\begin{array}{l}\text { To evaluate the } \\
\text { effect of Linear } \\
\text { peristaltic pump } \\
\text { on the integrity of } \\
\text { the erythrocytes. }\end{array}$ & $\begin{array}{l}\text { Ex- } \\
\text { perimental } \\
\text { controlled } \\
\text { study in } \\
\text { vitro }\end{array}$ & $\begin{array}{l}\text { - } 38 \text { samples of } \mathrm{CH} \text { and } \mathrm{ST} \text { periods } \\
\text { of storage: } 72 \text { hours and } 72 \\
\text { hours after the date of validity. } \\
\text { - Speeds of infusion: } 999 \mathrm{~mL} / \mathrm{h}, \\
100 \mathrm{~mL} / \mathrm{h}, 50 \mathrm{~mL} / \mathrm{h} \text { and } 5 \mathrm{~mL} / \mathrm{h} \text {. } \\
\text { - With the speed of infusion being } \\
50,100 \text { and } 999 \mathrm{~mL} / \mathrm{h} \text { storage } \\
\text { with solution at } \mathrm{SAG}-\mathrm{M}^{\text {Tr }} \text { and } 5 \\
\mathrm{~mL} / \mathrm{h} \text { stored in } \mathrm{CPDA}-1 \text {, the last } \\
\text { mimicked clinical neonatal period. } \\
\text { Variables of outcome: } \mathrm{Hb} \text { free in } \\
\text { the plasma and potassium free } \\
\text { in plasma. }\end{array}$ & $\begin{array}{l}\text { Erythrocyte collected } \\
\text { at the least amount of } \\
\text { time with potassium } \\
\text { and Hb free statistically } \\
\text { less than the group with } \\
\text { greater time. In } 18 \text { of } \\
\text { the } 20 \text { units the ST had } \\
72 \text { hours of collection. } \\
\mathrm{Hb} \text { free, there was an } \\
\text { increase by } 100 \% \text {, with } \\
\text { the results inside the } \\
\text { standards of quality. } \\
\text { Conclusion was that } \\
\text { BI in studies is apt for } \\
\text { transfusion. }\end{array}$ & $\begin{array}{l}\text { Emphasis on the time of } \\
\text { storage and in the evalu- } \\
\text { ation of the preservative } \\
\text { solution with higher } \\
\text { levels potassium in } \\
\text { CPDA-1 and lower stor- } \\
\text { age times. }\end{array}$ \\
\hline $\begin{array}{l}\text { Criss VR, } \\
\text { DePalma L, } \\
\text { Luban NLC. } \\
\text { Washington DC, } \\
\text { EUA, 1993(24) }\end{array}$ & $\begin{array}{l}\text { To evaluate the } \\
\text { effect of Linear } \\
\text { peristaltic pump } \\
\text { on the integrity } \\
\text { of the cells in dif- } \\
\text { ferent infusion } \\
\text { fluxes. }\end{array}$ & $\begin{array}{l}\text { Ex- } \\
\text { perimental } \\
\text { controlled } \\
\text { study in } \\
\text { vitro }\end{array}$ & $\begin{array}{l}\text { - } \quad 24 \mathrm{CH}^{+} \text {in solution CPDA-1. } \\
6 \text { experimental groups based on } \\
\text { manipulating the erythrocytes } \\
\text { (washed, radiated and filtered) } \\
\text { and infusion speed. } \\
\text { Variables of outcome: Hb, hema- } \\
\text { tocrit, number of erythrocytes, } \\
\mathrm{Hb} \text { free, } \mathrm{LDH} \text {, potassium, alanine } \\
\text { aminotransferase and Aspartate } \\
\text { Aminotransferase. }\end{array}$ & $\begin{array}{l}\mathrm{Hb} \text { free, potassium and } \\
\text { LDH were greater in the } \\
\text { erythrocyte (washed) } \\
\text { and radiated groups. } \\
\text { LDH altered significantly } \\
\text { in the manipulated eryth- } \\
\text { rocytes, however without } \\
\text { clinical relevance. } \\
\text { Recommendation is for } \\
\text { leuko-reduction for more } \\
\text { safety. }\end{array}$ & $\begin{array}{l}\text { Prior manipulation of } \\
\text { blood components as } \\
\text { risk factors for cellular } \\
\text { damage. Importance of } \\
\text { new study with these } \\
\text { erythrocyte sub-products } \\
\text { to define the evaluation } \\
\text { parameters to use. }\end{array}$ \\
\hline
\end{tabular}




\begin{tabular}{|c|c|c|c|c|c|}
\hline $\begin{array}{c}\text { Authors/Place/ } \\
\text { Year }\end{array}$ & Objective & $\begin{array}{l}\text { Type of } \\
\text { Design } \\
\text { Study }\end{array}$ & Sample and Interventions & $\begin{array}{l}\text { Results and } \\
\text { Conclusion }\end{array}$ & $\begin{array}{c}\text { Implications in } \\
\text { the practice of } \\
\text { transfusions for } \\
\text { nursing }\end{array}$ \\
\hline $\begin{array}{l}\text { Hansen TG, } \\
\text { Sprogoe- } \\
\text { Jacobsen U, } \\
\text { Pedersen CM, } \\
\text { Skovgaard } \\
\text { Olsen K, Risom } \\
\text { Kristensen, S } \\
\text { Escandinávia, } \\
\text { Dinamarca, } \\
1998^{(25)}\end{array}$ & $\begin{array}{l}\text { To evaluate } \\
\text { hemolysis in } \\
\text { peristaltic rotary } \\
\text { mechanisms and } \\
\text { pressurized infu- } \\
\text { sion systems. }\end{array}$ & $\begin{array}{l}\text { Experi- } \\
\text { mental and } \\
\text { random- } \\
\text { ized study } \\
\text { in vitro }\end{array}$ & $\begin{array}{l}\text { - } \quad \text { Total de } 30 \mathrm{CH} \text {. } \\
\text { Intervention } 1: 20 \text { units with eight } \\
\text { to } 11 \text { days of collection } \\
\text { Intervention 2: ten units with } 25 \\
\text { to } 33 \text { days of collection } \\
\text { Variables of outcome: hemolysis } \\
\text { percentage, } \mathrm{Hb} \text { free, hematocrit, } \\
\text { potassium and } \mathrm{LDH} \text {. }\end{array}$ & $\begin{array}{l}\text { Intervention } 1 \text { there was } \\
\text { no difference between } \\
\text { infusion systems and } \\
\text { LDH with marginal modi- } \\
\text { fications. Intervention } \\
2, \mathrm{Hb} \text { free, potassium, } \\
\mathrm{LDH} \text { and hematocrit } \\
\text { increased significantly } \\
\text { in relation to experi- } \\
\text { ment } 1 . \text { Conclusion - no } \\
\text { significant hemolysis } \\
\text { and the equipment are } \\
\text { safe alternatives for fast } \\
\text { transfusions. }\end{array}$ & $\begin{array}{l}\text { Importance of evaluation } \\
\text { of equipment variables } \\
\text { concerning the infusion } \\
\text { pressure and occlusion } \\
\text { for the prevention of } \\
\text { cellular damage. Rotary } \\
\text { equipment obtained } \\
\text { higher fluxes than the } \\
\text { pressurized system that } \\
\text { had constant pressure at } \\
300 \mathrm{mmHg} \text {. }\end{array}$ \\
\hline $\begin{array}{l}\text { Rojas JT et al } \\
\text { Granada, } \\
\text { Spain, 2001(26) }\end{array}$ & $\begin{array}{l}\text { To determine } \\
\text { hemolysis in } \mathrm{BI} \\
\text { volumetric infu- } \\
\text { sion pumps using } \\
\text { cassettes. }\end{array}$ & $\begin{array}{l}\text { Ex- } \\
\text { perimental } \\
\text { controlled } \\
\text { study in } \\
\text { vitro }\end{array}$ & $\begin{array}{l}\text { - } 55 \text { transfusions with total of } 110 \\
\text { measures of biomarkers. } \\
\text { Samples collected from controlled } \\
\text { experiments after } 2 \text { hours and } 30 \\
\text { minutes. } \\
\mathrm{CH}^{+} \text {with average of } 14,38 \text { days } \\
\text { of collection, with greater hemoly- } \\
\text { sis from } 75 \text { percent. } \\
\text { Variables of outcome: Hb free, } \\
\text { hematocrit, potassium and LDH. }\end{array}$ & $\begin{array}{l}\text { Increase of potassium } \\
\text { associated to the via, } \\
\text { existence of other } \\
\text { infusions, greater flux, } \\
\text { storage and greater } \\
\text { hematocrit. LDH showed } \\
\text { statistical differences } \\
\text { in the cassette BI with } \\
\text { a lower gauge, and } \\
\text { at the same time } \\
\text { other infusions and older } \\
\text { blood. Conclusion - the } \\
\text { peristaltic BI and the } \\
\text { cassette can be used by } \\
\text { nurses. }\end{array}$ & $\begin{array}{l}\text { The BI was considered } \\
\text { safe, however before the } \\
\text { therapy is introduced, } \\
\text { it is fundamental to } \\
\text { have an evaluation of } \\
\text { the inherent aspects of } \\
\text { the blood components } \\
\text { (storage), the devices } \\
\text { for infusion (flows, pres- } \\
\text { sure and catheter) and } \\
\text { consideration for the } \\
\text { additional biomarkers } \\
\text { such as LDH and potas- } \\
\text { sium. }\end{array}$ \\
\hline $\begin{array}{l}\text { Frey B, } \\
\text { Eber S, } \\
\text { Weiss M, } \\
\text { Zurique, Suiça, } \\
2003^{(27)}\end{array}$ & $\begin{array}{l}\text { To evaluate } \\
\text { the effect of BI } \\
\text { with syringe } \\
\text { pumps, Linear } \\
\text { peristaltic pump } \\
\text { and volumetric } \\
\text { infusion pumps } \\
\text { with the Shuttle } \\
\text { mechanism on } \\
\text { the integrity of } \\
\text { the erythrocyte. }\end{array}$ & $\begin{array}{l}\text { Ex- } \\
\text { perimental } \\
\text { controlled } \\
\text { study in } \\
\text { vitro }\end{array}$ & $\begin{array}{l}\text { - } 8 \text { units of } \mathrm{CH}^{\dagger} \text { and } \mathrm{ST} \text {, in solution } \\
\text { of CPDA- } 1 \text { with } 50 \mathrm{ml} \text { for each. } \\
\text { All of the units were leuko- } \\
\text { reduced. } \\
2 \text { storage groups: } 27 \text { days, as } \\
\text { young people and } 43 \text { to } 51 \text { days, } \\
\text { the oldest. } \\
\text { Flux was } 20 \mathrm{~mL} / \mathrm{h} \text { and the infusion } \\
\text { duration was } 2.5 \text { hours, simulating } \\
\text { neonatal transfusions. At the end } \\
\text { of the infusion line of the } 3 \text { pumps } \\
\text { were connections to the catheter } \\
\text { at } 24 \mathrm{G} \text { and the intravenous pres- } \\
\text { sure simulation was } 15 \mathrm{mmHg} \text {. } \\
\text { Variables of outcome: } \mathrm{Hb} \text {, aver- } \\
\text { age cospuscular volume, osmotic } \\
\text { fragility, } \mathrm{LDH}, \text { potassium, total } \\
\text { bilirubin and Hb free. }\end{array}$ & $\begin{array}{l}\text { Greater potassium, } \mathrm{Hb} \\
\text { free osmotic fragility } \\
\text { and average corpuscular } \\
\text { volume in longer storage } \\
\text { periods. BI for syringe } \\
\text { pumps and linear } \\
\text { peristaltic pump showed } \\
\text { higher levels of Hb free } \\
\text { and LDH than Shuttle. } \\
\text { Conclusion - the volu- } \\
\text { metric Shuttle caused } \\
\text { less hemolysis. }\end{array}$ & $\begin{array}{l}\text { Study mimicked neo- } \\
\text { natal transfusions. The } \\
\text { alterations observed } \\
\text { were significant and } \\
\text { were influenced by the } \\
\text { storage time and type } \\
\text { of BI, being the Shuttle } \\
\text { mechanism which was } \\
\text { considered safe. }\end{array}$ \\
\hline $\begin{array}{l}\text { Carvalho EB, } \\
\text { Borges EL, } \\
\text { Carlos LMB } \\
\text { et al } \\
\text { Ceará, Brasil, } \\
2007^{(28)}\end{array}$ & $\begin{array}{l}\text { To evaluate } \\
\text { hemolysis in } \mathrm{BI} \\
\text { linear peristaltic } \\
\text { rotary pumps } \\
\text { and two linear } \\
\text { peristaltic pumps } \\
\text { (volumetric infu- } \\
\text { sion pumps and } \\
\text { Flow meters). }\end{array}$ & $\begin{array}{l}\text { Ex- } \\
\text { perimental } \\
\text { controlled } \\
\text { study in } \\
\text { vitro }\end{array}$ & $\begin{array}{l}\text { - } 36 \mathrm{CH} \text { with less than ten days of } \\
\text { collection. } \\
\text { Speeds of analyzed infusion: } \\
\mathrm{V} 1=120 \mathrm{~mL} / \mathrm{h} ; \mathrm{V} 2=240 \mathrm{~mL} / \mathrm{h} ; \\
\mathrm{V} 3=360 \mathrm{~mL} / \mathrm{h} . \\
\text { Variables of outcome: } \mathrm{Hb} \text { free, } \\
\text { percentage of hemolysis and } \\
\text { potassium. }\end{array}$ & $\begin{array}{l}\text { There was no statistical- } \\
\text { ly significant hemolysis } \\
\text { amongst the Bl. Equip- } \\
\text { ment designated as safe } \\
\text { for transfusions. }\end{array}$ & $\begin{array}{l}\text { Mechanism considered } \\
\text { safe for transfusions. } \\
\text { SAG- M solution } \\
\text { reduced the final hema- } \\
\text { tocrit. Blood components } \\
\text { with existing hematocrit, } \\
\text { higher and more likely } \\
\text { to have cellular damage } \\
\text { during transfusions. }\end{array}$ \\
\hline $\begin{array}{l}\text { Parfitt HS, } \\
\text { Davies SV, } \\
\text { Tighe, P, } \\
\text { Ewings P, } \\
\text { Inglaterra, } \\
2007^{(29)}\end{array}$ & $\begin{array}{l}\text { To evaluate } \\
\text { the cellular } \\
\text { damage in two } \\
\text { Bls using the } \\
\text { linear peristaltic } \\
\text { mechanism. }\end{array}$ & $\begin{array}{l}\text { Ex- } \\
\text { perimental } \\
\text { controlled } \\
\text { study in } \\
\text { vitro }\end{array}$ & $\begin{array}{l}\text { - } \\
\text { Six } \mathrm{CH} \text { at storage rates with } \\
\text { SAG-M. } \\
\mathrm{CH}^{+} \text {with } 9,28 \text { and } 35 \text { days of } \\
\text { collection. } \\
\text { Flux: } 40 \mathrm{~mL} / \mathrm{h} \text { infused in } 4 \text { hours } \\
\text { simulating pediatric practices } \\
\text { and } 150 \mathrm{~mL} / \mathrm{h} \text { infused in } 2 \text { hours } \\
\text { simulating the practice in adults. } \\
\text { Carried out gravity tests as } \\
\text { controls. } \\
\text { Variables outcomes: potassium } \\
\text { and Hb free. }\end{array}$ & $\begin{array}{l}\text { The potassium and } \mathrm{Hb} \\
\text { free increased during } \\
\text { each storage period. } \\
\text { The flows influenced in } \\
\text { the hemolysis. Conclu- } \\
\text { sion - B has hemolytic } \\
\text { potential principally in } \\
\mathrm{CH} \text { with longer storage } \\
\text { times. }\end{array}$ & $\begin{array}{l}\text { Blood used in rates } \\
\text { without evaluation of the } \\
\text { original bag and blood } \\
\text { components. Period } \\
\text { of storage greater with } \\
\text { higher presence of } \\
\text { hemolysis. }\end{array}$ \\
\hline
\end{tabular}




\begin{tabular}{|c|c|c|c|c|c|}
\hline $\begin{array}{c}\text { Authors/Place/ } \\
\text { Year }\end{array}$ & Objective & $\begin{array}{l}\text { Type of } \\
\text { Design } \\
\text { Study }\end{array}$ & Sample and Interventions & $\begin{array}{l}\text { Results and } \\
\text { Conclusion }\end{array}$ & $\begin{array}{l}\text { Implications in } \\
\text { the practice of } \\
\text { transfusions for } \\
\text { nursing }\end{array}$ \\
\hline $\begin{array}{l}\text { Frey B, } \\
\text { Eber S, } \\
\text { Weiss M, } \\
\text { Zurique, Suíça, } \\
2003^{(27)}\end{array}$ & $\begin{array}{l}\text { To evaluate } \\
\text { the effect of BI } \\
\text { with syringe } \\
\text { pumps, Linear } \\
\text { peristaltic pump } \\
\text { and volumetric } \\
\text { infusion pumps } \\
\text { with the Shuttle } \\
\text { mechanism on } \\
\text { the integrity of } \\
\text { the erythrocyte. }\end{array}$ & $\begin{array}{l}\text { Ex- } \\
\text { perimental } \\
\text { controlled } \\
\text { study in } \\
\text { vitro }\end{array}$ & $\begin{array}{l}\text { - } 8 \text { units of } \mathrm{CH}^{+} \text {and } \mathrm{ST} \text {, in solution } \\
\text { of } \mathrm{CPDA}-1 \text { with } 50 \mathrm{ml} \text { for each. } \\
\text { All of the units were leuko- } \\
\text { reduced. } \\
2 \text { storage groups: } 27 \text { days, as } \\
\text { young people and } 43 \text { to } 51 \text { days, } \\
\text { the oldest. } \\
\text { Flux was } 20 \mathrm{~mL} / \mathrm{h} \text { and the infusion } \\
\text { duration was } 2.5 \text { hours, simulating } \\
\text { neonatal transfusions. At the end } \\
\text { of the infusion line of the } 3 \text { pumps } \\
\text { were connections to the catheter } \\
\text { at } 24 \mathrm{G} \text { and the intravenous pres- } \\
\text { sure simulation was } 15 \mathrm{mmHg} \text {. } \\
\text { Variables of outcome: } \mathrm{Hb} \text {, aver- } \\
\text { age cospuscular volume, osmotic } \\
\text { fragility, } \mathrm{LDH}, \text { potassium, total } \\
\text { bilirubin and } \mathrm{Hb} \text { free. }\end{array}$ & $\begin{array}{l}\text { Greater potassium, } \mathrm{Hb} \\
\text { free osmotic fragility } \\
\text { and average corpuscular } \\
\text { volume in longer storage } \\
\text { periods. Bl for syringe } \\
\text { pumps and linear } \\
\text { peristaltic pump showed } \\
\text { higher levels of Hb free } \\
\text { and LDH than Shuttle. } \\
\text { Conclusion - the volu- } \\
\text { metric Shuttle caused } \\
\text { less hemolysis. }\end{array}$ & $\begin{array}{l}\text { Study mimicked neo- } \\
\text { natal transfusions. The } \\
\text { alterations observed } \\
\text { were significant and } \\
\text { were influenced by the } \\
\text { storage time and type } \\
\text { of BI, being the Shuttle } \\
\text { mechanism which was } \\
\text { considered safe. }\end{array}$ \\
\hline $\begin{array}{l}\text { Carvalho EB, } \\
\text { Borges EL, } \\
\text { Carlos LMB } \\
\text { et al } \\
\text { Ceará, Brasil, } \\
2007^{(28)}\end{array}$ & $\begin{array}{l}\text { To evaluate } \\
\text { hemolysis in BI } \\
\text { linear peristaltic } \\
\text { rotary pumps } \\
\text { and two linear } \\
\text { peristaltic pumps } \\
\text { (volumetric infu- } \\
\text { sion pumps and } \\
\text { Flow meters). }\end{array}$ & $\begin{array}{l}\text { Ex- } \\
\text { perimental } \\
\text { controlled } \\
\text { study in } \\
\text { vitro }\end{array}$ & $\begin{array}{l}\text { - } 36 \mathrm{CH} \text { with less than ten days of } \\
\text { collection. } \\
\text { Speeds of analyzed infusion: } \\
\mathrm{V} 1=120 \mathrm{~mL} / \mathrm{h} ; \mathrm{V} 2=240 \mathrm{~mL} / \mathrm{h} \text {; } \\
\mathrm{V} 3=360 \mathrm{~mL} / \mathrm{h} \text {. } \\
\text { Variables of outcome: } \mathrm{Hb} \text { free, } \\
\text { percentage of hemolysis and } \\
\text { potassium. }\end{array}$ & $\begin{array}{l}\text { There was no } \\
\text { statistically significant } \\
\text { hemolysis amongst } \\
\text { the Bl. Equipment } \\
\text { designated as safe for } \\
\text { transfusions. }\end{array}$ & $\begin{array}{l}\text { Mechanism considered } \\
\text { safe for transfusions. } \\
\text { SAG- M solution } \\
\text { reduced the final } \\
\text { hematocrit. Blood } \\
\text { components with } \\
\text { existing hematocrit, } \\
\text { higher and more likely } \\
\text { to have cellular damage } \\
\text { during transfusions. }\end{array}$ \\
\hline $\begin{array}{l}\text { Parfitt HS, } \\
\text { Davies SV, } \\
\text { Tighe, P, } \\
\text { Ewings P, } \\
\text { Inglaterra, } \\
2007^{(29)}\end{array}$ & $\begin{array}{l}\text { To evaluate } \\
\text { the cellular } \\
\text { damage in two } \\
\text { Bls using the } \\
\text { linear peristaltic } \\
\text { mechanism. }\end{array}$ & $\begin{array}{l}\text { Ex- } \\
\text { perimental } \\
\text { controlled } \\
\text { study in } \\
\text { vitro }\end{array}$ & $\begin{array}{l}\text { - } \mathrm{Six} \mathrm{CH} \text { at storage rates with } \\
\text { SAG-M. } \\
\mathrm{CH}^{+} \text {with } 9,28 \text { and } 35 \text { days of } \\
\text { collection. } \\
\text { Flux: } 40 \mathrm{~mL} / \mathrm{h} \text { infused in } 4 \text { hours } \\
\text { simulating pediatric practices } \\
\text { and } 150 \mathrm{~mL} / \mathrm{h} \text { infused in } 2 \text { hours } \\
\text { simulating the practice in adults. } \\
\text { Carried out gravity tests as } \\
\text { controls. } \\
\text { Variables outcomes: potassium } \\
\text { and } \mathrm{Hb} \text { free. }\end{array}$ & $\begin{array}{l}\text { The potassium and } \mathrm{Hb} \\
\text { free increased during } \\
\text { each storage period. } \\
\text { The flows influenced in } \\
\text { the hemolysis. Conclu- } \\
\text { sion - B has hemolytic } \\
\text { potential principally in } \\
\mathrm{CH} \text { with longer storage } \\
\text { times. }\end{array}$ & $\begin{array}{l}\text { Blood used in rates } \\
\text { without evaluation of the } \\
\text { original bag and blood } \\
\text { components. Period } \\
\text { of storage greater with } \\
\text { higher presence of } \\
\text { hemolysis. }\end{array}$ \\
\hline $\begin{array}{l}\text { Lieshout-Krikk } \\
\text { RW, } \\
\text { Van der Meer } \\
\text { PF, } \\
\text { Koopman } \\
\text { MMW, } \\
\text { Korte D. } \\
\text { Amsterdam, } \\
\text { Holand, 2011(10) }\end{array}$ & $\begin{array}{l}\text { To investigate } \\
\text { hemolysis in } \mathrm{BI} \\
\text { for the linear peri- } \\
\text { staltic pump. }\end{array}$ & $\begin{array}{l}\text { Ex- } \\
\text { perimental } \\
\text { controlled } \\
\text { study in } \\
\text { vitro }\end{array}$ & $\begin{array}{l}\text { - Ten } \mathrm{Bl} \text { linear peristaltic pumps. } \\
11 \text { units of } \mathrm{CH} \text { stored in CPDA-1. } \\
\text { With } 30 \text { to } 35 \text { days of collection. } \\
10 \text { infused by } \mathrm{Bl} \text { and } 1 \text { using } \\
\text { gravity. } \\
\text { - } \quad \text { Flux of } \mathrm{Bl}: 100 \mathrm{~mL} / \mathrm{h} \text { and } 300 \mathrm{~mL} / \mathrm{h} \text {. } \\
\text { Variables of outcome: } \mathrm{Hb} \text { free, } \\
\text { counting red blood cells, } \mathrm{Hb} \text { total, } \\
\text { morphology of red blood cells, } \\
\text { potassium free, and connections } \\
\text { with anexins } \mathrm{A} 5 \text { in the red blood } \\
\text { cells. }\end{array}$ & $\begin{array}{l}\text { There was no hemolysis } \\
\text { in the flows of } 100 \mathrm{~mL} / \mathrm{h} \\
\text { and } 300 \mathrm{~mL} / \mathrm{h} \text {. Bl linear } \\
\text { peristaltic pump lineares } \\
\text { recommended for blood } \\
\text { transfusions. }\end{array}$ & $\begin{array}{l}\text { Peristaltic mechanisms } \\
\text { considered safe for } \\
\text { transfusions even in } \\
\text { worse storage scenario. }\end{array}$ \\
\hline
\end{tabular}

* Gauge; † Concentrated red blood cells; \pm Milliliters; § Milliliters per hour; | | Hemoglobin; q Citrate phosphate dextrose adenine; ** infusion pumps; †† Blood total; \pm \pm Dose of absorbed radiation§§ Millimeters of mercury; | || | Lactate Dehydrogenase; ๆๆ Saline-adenine-glucose-mannitol.

Figure 3 - Summary of the studies that were analyzed with reference to the authors, the objective of the study, the results, type of study, results and conclusion and implications for practices in nursing. 


\section{Infusion pump mechanisms}

Amongst the 17 studies that were selected, we identified 40 types of infusion systems used in transfusion therapy with $39(97.5 \%)$ being $\mathrm{BI}$ and 01 $(2.5 \%)$ being a pressure system. Some work opted for analyzing just the infusion mechanism in isolation or the different manufacturers while others evaluated the differences between the mechanisms.

The studies covered volumetric infusion pumps, Flow meters and syringe pumps that, in one study, the type of devices were not described. Of the 39 that were described, volumetric infusion pumps were described the most ( 32 or $82.0 \%$ ). The next were 5 syringe pumps $(12.8 \%)$ and lastly 2 flow meters (5.2\%).

Amongst the total number of pumps described, the following infusion mechanism were found: five $(12.8 \%)$ syringe pumps, nine $(23.1 \%)$ cassette types, $22(56.4 \%)$ linear peristaltic pumps, two (5.1\%) rotary pumps and one $(2.6 \%)$ using the shuttle mechanism.

With reference to the infusion mechanism, the linear peristaltic pump was the type that provoked the most amount of hemolysis. It was stated that hemolytic events could be predicted according to 10 (76.9\%) publications of the 13 that were studied covering linear peristaltic pumps. Others studies state that the BI that is considered the safest for therapeutic transfusions is the volumetric infusion pumps using the cassette mechanism. This was mentioned in four studies (or $66.7 \%$ out of six) with results that showed how safe it was.

Simulation studies were done with reference to infusion flux based on clinical practices for transfusions done in pediatrics/neonatal care and for adults. The speeds of infusion varied from five mil liters per hour $(\mathrm{mL} / \mathrm{h})$ to $999 \mathrm{~mL} / \mathrm{h}$.

In relation to infusion pressure, two of the studies $(11.8 \%)$ covered an inflatable pressurized device with a pressure gauge. The other was able to obtain the maximum pressure for linear peristaltic pumps ${ }^{(20,25)}$.

\section{Cellular damage}

Out of the 17 studies, the blood components which were prevalent were the $\mathrm{CH}$ in 10 of them (58.8\%). One (5.9\%) only used the ST and six (35.3\%) evaluated both blood products in the experiments.

In relation to the preservative solution, eight (47.1\%) used the citrate phosphate dextros and adenine solutions (CPDA-1). Four (23.5\%) used additives based on mannitol. Four (23.5\%) did not specify the preservative solution used and one (5.9\%) analyzed samples of both solutions. None of the publications focused on the propensity for hemolytic effects to occur based on the preservative solution. Only two studies suggested $(11.8 \%)$ that solutions with additives reduced the final hematocrit in the bag. This in turn reduces the viscosity of the blood components.

In relation to storage time, the time period for storing hemolysis varied from 24 to 44 days. In eight studies $(47.1 \%)$ there was a description of a lot of hemolysis when the erythrocytes were near to expiration ${ }^{(16,18,26-27,29)}$.

In the life span of the hemolysis there is a liberation of hemoglobin in the plasma. There is also an increase in potassium and lactic dehydrogenase (LDH) amongst other biomarkers. In the selected article, the integrity of the cells were analyzed through variables of outcome such as free hemoglobin, hematocrit, potassium, LDH, percentage of hemolysis, a wide distribution of red blood cells, average corpuscular volume, the number of erythrocytes, alanine aminotransferase and aspartate aminotransferase. Free hemoglobin was the biomarker most present in all of the publications. Potassium was the second hemolysis marker that was most prevalent being described in $11(64.7 \%)$ of the studies included. Of these, nine $(53.0 \%)$ related to the increase in potassium at the longest storage period for the hemotherapeutic product.

With reference to establishing hemolysis as the results of the action of the infusion system in the cells, $10(58,9 \%)$ articles covered this area. Four publications $(23.5 \%)$ noted significant statistical alterations in the outcome variables. However they opted on determining the presence of hemolysis being clinically significant for values where the level of hemolysis was above $0.8 \%(18,20,25,28)$.

None of the publications mentioned the clinical consequences of cellular damage and the liberation of biomarkers to patients.

\section{Discussion}

The studies selected in the literature show that alterations in the integrity of the erythrocytes can occur when $\mathrm{CH}$ and ST are transfused by BI. This is that case for the action with the infusion mechanism and the variables related to the equipment such as flux.

All of the evidence found in the study came from simulations done in laboratories. Humans were not used in the simulations. These studies were called pre-clinical studies. Publications that rate the level of scientific research on a scale of I to VIII with level I covering systematic meta-analysis revisions which are considered the best evidence, refers to pre-clinical studies with animals. In vitro studies are considered to be VIII on the scale ${ }^{(31)}$. However they are considered 
fundamental evidence for investigating theories which can be subsequently evaluated and implemented in future clinical studies.

Even with a low level of evidence in the in vitro studies, it is still possible to evaluate the methodological rigor of the publications from the way how the studies have been designed, with 16 (94.1\%) covering controlled evaluations and 01 (5.9\%) covering controlled randomized studies.

Cellular damage of the red blood cells during the period of the extravascular hemolysis can have damaging clinical consequences for the patient. This is because low levels of functioning hemoglobin are produced and renal problems can occur (such as hemoglobinemia, hemoglobinuria and acute renal problems). There can also be alterations in substances that point to hemolysis such as LDH, haptoglobin and potassium(9-10,32).

Free potassium in the plasma can bring about adverse events for the patient such as arrhythmia and even sudden death. Other correlated studies increased the level of potassium with an increase in storage time and the preservative solution in the collection bag ${ }^{33-35)}$. There is evidence of the occurrence of hyperkalemia and even heart attacks when there are transfusions with $\mathrm{CH}$ after long storage periods ${ }^{(33-35)}$. The concentrations of potassium in the stored blood increase about 1 milliequivalent (mEq) per day ${ }^{(9)}$. However none of the publications that were selected touched on the clinical consequences of cellular damage to patients because they mainly dealt with in vitro studies. In spite of this, they placed a lot of emphasis on the biomarkers as a consequence of cellular damage and hemolysis.

Nowadays, national agencies, Europeans and North Americans establish a maximum level of hemolysis at $0.8 \%$ until the last storage day. This is obligatory in the control of the quality of blood banks ${ }^{(36)}$. In some included studies the authors designated hemolysis through alterations in the markers after the experiments. Others adopt a reference value for the level of hemolysis at $0.8 \%$ for clinical relevant hemolysis. The value designated to control the quality of the $\mathrm{CH}$ in blood banks in Brazil is defined by the Resolution from the Governing Collegiate (RDC) Number 34, 11 June 2014. It stated that the acceptable hemolysis is a maximum of $0.8 \%$ at the last time period for storage which is about the 35th day in conservative solutions that have CPDA-1(37).

Another point that was explored as a factor in damaging red blood cells, was the storage time for ST and $\mathrm{CH}$. Some research noted that red blood cells at the last time period for expiration are very fragile and are susceptible to hemolytic effects. The solutions commonly used CPDA-1 that conserves the $\mathrm{CH}$ for 35 days and the additives solutions that preserve erythrocytes for
42 days. Publications suggest that the preservative solutions saline-adenine-glucosemannitol (SAG-M) reduces the final hematocrit for blood components, however further research should focus on the differences between preservative solutions, hematocrit and blood components such as red blood cells leukoreduced, washed and radiated ${ }^{(19,28)}$.

The linear peristaltic mechanisms were the most susceptible at producing hemolysis, according to the articles. 13 studies were evaluated in this revision. 3 (23.1\%) of them considered it to be a safe mechanism for transfusions. The flow meters BIs mentioned in two publications are not currently recommended for intravenous therapy because they require electronic sensors that count the drips to measure and administer the volume of liquid. However it does not consider the viscosity, density, superficial tension and solution temperature which are important determinants for measuring the drips to be administered ${ }^{(6)}$..

The volumetric mechanism with the cassette is efficient and excellent for intravenous therapy. This is because it has little interference with the mechanical force of the BI on the fluid to be administered. In the articles included in the present revision, it was identified as a safe mechanism for blood transfusions(6,17,21-22.26).

An English studied noted that hemolysis is caused by multi factors associated with the increase in hematocrit, storage time for the blood components and the pressure placed on the red blood cells ${ }^{(9)}$. The manufacturers ought to pay attention to the international standard in the International Organization for Standardization (ISO) $1135-4^{(38)}$, that determines the maximum pressure level for infusion at 40 kilopascal $(\mathrm{kPa})^{(9,25,38)}$. No publication stated the value of the infusion pressure as a possible factor for cellular damage. They only stated the pressor variation in the equipment in high infusion fluxes(20). Aspects related to accessories to infusion pumps such as catheters, were described and evaluated only in conjunction with the infusion system. This gave us inconclusive and conflicting results.

The linear peristaltic pumps are the most common pumps in the health care system in the country. They have advantages in comparison to the cassette system, such as similar alarms and their accessories are less onerous ${ }^{(6)}$. More studies in the linear peristaltic pumps should be done to established standards for its use. The studies should also cover: infusion pressure and occlusion, defining the worst case scenario, fluxes that mimic the practice of transfusions, temperature control during the procedure and a wide analysis of biomarkers for evaluation of hemolysis which has consensus in the literature. 
We reiterate the importance of institutional protocols for blood banks and assistant units that ensure safety in the transfusion process to prevent untoward events. For example there can be double checks of the blood component data and the individual who will receive the blood. Health and safety analysis of the equipment can be conducted for transfusions in institutions. There can also be: more improvements made in the technology used and more visual inspections of the collection bags because this visual check may be useful in detecting hemolysis (note this has not be proven) ${ }^{(39)}$.

Multi professional teams need to do the following to implement the use of this transfusion therapy: prescribe the blood product, plan the installation of the transfusion therapy, choose the catheter and the accessories for adequate infusion, obtain an access route, technical installation, monitoring patient responses, infusion control (time, volume, adverse reactions), prevention of complications and constantly monitoring the infusion. In the team, the nurse evaluates and implements the intravenous therapy and selects the adequate materials for the patient and the treatment ${ }^{(5)}$. In the publications that we studied there was a greater likelihood for hemolysis with catheters at low gauges principally where there are high flows. This is due to the force of the blood with few lumes. Nevertheless, all of the researchers evaluated the infusion system as a whole being part of BIs with the catheter and not only the catheter in isolation $(8,18,26)$.

The technology is a part of everyday nursing. Progress in the use of BI in intravenous therapy has provided greater safety and efficiency in the process through the use of resources that facilitate and improve nursing in relation to: volume control, infusion time, memory of stunted infusions and the establishment of infusion pressure ${ }^{(4)}$.

The theme of safety for the patient is an important tool in the management of institutional processes and it has been receiving special attention in the world at large. In order to promote safety it is essential that all those involved understand clinical practices and techniques that are used to ensure low risks in transfusions. This being the case, an evaluation of the target public's characteristics is fundamental covering: age group, clinical state and blood component indicators. Other aspects include: variables related to devices and equipment, accuracy, influence of the hydrostatic pressure, solution type, the quality of the flux, system safety and evaluate costing issues.

The following should be implemented and adhered to, in order to ensure transfusion safety: the development of protocols covering the parameters for uniformed evaluations and improvements in future equipment through better technology. For example, incentives should be given for the use of devices which are intelligent BIs that can alert the professional where there is the possibility of errors or when there are alterations in the safety standards. These devices are computerized and are thus connected to the patient's medical records when admitted to hospital. They can be adjusted to clinical needs and produce more efficiency in nursing. This is because notes can be directly placed on the electronic patient record as well as noting: the dose, time, type and volume of the medicine of infused solution $^{(40)}$. This is technology that has been well developed and used in north American and European countries in spite of being expensive. Future studies covering cost and benefits for the implementation of intravenous therapy in relation to transfusion ought to focus on improving the process and work of nurses and the safety for patients at the edges of the hospital beds.

\section{Conclusion}

The studies selected in the literature show that alterations in the integrity of the erythrocytes can occur when $\mathrm{CH}$ and ST are transfused by BI. Amongst the different types and BI mechanisms, the safest for transfusions are volumetric infusion pumps with the cassette mechanism. The linear peristaltic pumps are more likely to produce hemolytic effects. With reference to variable infusion speeds, based on the analyzed equipment, we found a divergence in the results.

We noted that the storage time for the blood components to be transfused can influence the increase in cellular fragility. In other words, the nearer the expiration deadline for the blood product was, the greater the chances of there being hemolysis. Red blood cell damage was mentioned in the publications when biomarkers were released with the most common being free hemoglobin due to potassium. The level of hemolysis was a determinant in some publications, which opted to designate the hemolysis from the reference value of $0.8 \%$. None of the studies focused on the clinical consequences of extravascular hemolysis for the patient.

There was no conclusive evidence on the influence of the needle gauge with the catheter connected in the final infusion line, on the integrity of the erythrocytes for ST and $\mathrm{CH}$. We opted to evaluate the whole infusion system for some of the publications.

Investment in research and technology in relation to transfusion safety for the erythrocytes when using automated erythrocytes is extremely relevant. We need new research showing experiments that analyze the multi factors involved in hemolysis, which will in turn aid 
future studies that aim to promote safe practices for the protection of patients.

\section{Limitations of the Study}

We opted for not limiting the scope of the data and our searches, but some of the data was far from being relevant to the study. Although the theme was related to technology and innovation in transfusion therapy, there was a scarcity in publications on this topic covering the use of BIs in blood transfusions.

Additional we could not evaluate the quality of the methods used in the in vitro experimental studies as they did not fit into the system for classifying data from epidemiological studies. They were considered to be pre-clinical. We therefore opted to describe the rigor in the methods used.

\section{References}

1. Carson JL, Grossman BJ, Kleinman S, Tinmouth AT, Marques MB, Fung MK, et al. Red blood cell transfusion: a clinical practice guideline from the $A A B B$. Ann Intern Med. 2012;157:49-58.

2. Ministério da Saúde (BR). Secretaria de Atenção à Saúde. Coordenação Geral de Sangue e Hemoderivados. Caderno de informação: sangue e hemoderivados: produção hemoterápica. 4 ed, Brasília; 2014

3. Ministério da Saúde (BR). Secretaria de Atenção à Saúde, Coordenação Geral de Sangue e Hemoderivados. Caderno de informação: sangue e hemoderivados: produção hemoterápica. 4a ed. Brasília; 2011.

4. Philips LD. Manual of IV Therapeutics: evidencebased practice to infusion therapy. 5th ed. Philadelfia: F. A. Davis; 2010.

5. Conselho Federal de Enfermagem (BR). Resolução COFEN no 306/2006. Normatiza a atuação do Enfermeiro em Hemoterapia. Rio de Janeiro; 2006.

6. Harada MJCS, Pedreira MLG. Terapia Intravenosa e Infusões. São Caetano do Sul: Yendis; 2011.

7. Associação Brasileira de Normas Técnicas (ABNT). Prescrições particulares para a segurança de bombas e controladores de infusão. Rio de Janeiro; 1999. 84 p.

8. Emergency Care Research Institute (ECI). General purpose infusion 193 pumps. Health devices. 1998;27(45):123-70.

9. Nightingale MJ, Norfolk DR, Pinchon DJ. Current uses of transfusion administration sets: a cause for concern? Transfus Med. 2010;20(5):291-302.

10. Heaton A. Red blood cell hemolysis: an old standard in changing times. Transfusion. 2009;49(12):2551-4.

11. Beyea S, Nicoll LH. Writing an integrative review. AORN J. 1998;67(4):877-80.
12. Mendes KDS, Silveira RCCP, Galvão CM. Revisão integrativa: método de pesquisa para a incorporação de evidências na saúde e na enfermagem. Texto Contexto Enferm. 2008; 17(4):758-64.

13. Whittemore $R$, Knal $K$. The integrative review: updated methodology. J Adv Nurs. 2005;52(5):546-53. 14. Wilcox GJ, Barnes A, Modanlou H. Does transfusion using a syringe infusion pump and small-gauge needle cause hemolysis? Transfusion. 1981;21(6):750-1.

15. Herrera $A J$, Corless J. Blood transfusions: effect of speed of infusion and of needle gauge on hemolysis. J Pediatr. $1981 ; 99(5): 757-8$.

16. Gibson JS, Leff RD, Roberts RJ. Effects of intravenous delivery systems on infused red blood cells. Am J Hosp Pharm. 1984;41(3):468-72.

17. Veerman MW, Leff RD, Roberts RJ. Influence of two piston-type infusion pumps on hemolysis of infused red blood cells. Am J Hosp Pharm. 1985;42(3):626-8.

18. Thompson HW, Lasky LC, Polesky HF. Evaluation of a volumetric intravenous infusion pump for transfusion of blood components containing red cells. Transfusion. 1986;26(3):290-2.

19. Angel JL, O'Brien WF, Knuppel RA, Warren MB, Leparc GF. Infusion of packed erythrocytes: an in vitro study of hemolysis. Obstet Gynecol. 1987;69(6):948-50.

20. Gurdak RG, Anderson G, Mintz PD. Evaluation of IVAC Variable Pressure Volumetric Pump Model 560 for the delivery of red blood cells, adenine-saline added. Am J Clin Pathol. 1988;91(2):199-202.

21. Denison MUP, Bell R, Schuldreich R, Chaudhri MA. Effect of different pump mechanisms on transfusion of blood. Australas Phys Eng Sci Med. 1991;14(1):39-41.

22. Strayer AH, Henry DW, Erenberg A, Leff RD. Administration of whole blood, packed red blood cells, and platelets using a multipurpose infusion pump. Am J Hosp Pharm. 1991;48(9):1970-2.

23. Burch KJ, Phelps SJ, Constance TD. Effect of an infusion device on the integrity of whole blood and packed red blood cells. Am J Hosp Pharm. 1991;48(1):92-7.

24. Criss VR, DePalma L, Luban NL. Analysis of a linear peristaltic infusion device for the transfusion of red cells to pediatric patients. Transfusion.1993;33(10):842-4.

25. Hansen TG, Sprogoe-Jakobsen U, Pedersen CM, Olsen KS, Kristensen SR. Haemolysis following rapid experimental red blood cell transfusion: an evaluation of two infusion pumps. Acta Anaesthesiol Scand. 1998;42(1):57-62.

26. Rojas JT, Heras FB, García MRS, López EP, Vilchez MCM, Rodríguez JD. Volumetric pumps for blood transfusions: viability in pediatrics. 2001;24(11):8-12. 27. Frey B, Eber S, Weiss M. Changes in red blood cell integrity related to infusion pumps: a comparison of 
three different pump mechanisms. Pediatr Crit Care Med. 2003;4(4):465-70.

28. Carvalho EB, Borges EL, Carlos LMB, Silva MAM, Magalhães SMM, Gomes FVBAF, et al. Efeito da bomba de infusão de soluções sobre o grau de hemólise em concentrado de hemácias. Rev Bras Hematol Hemoter. 2007;29(2):149-52.

29. Parfitt HS, Davies SV, Tighe P, Ewings P. Red cell damage after pumping by two infusion control devices (Arcomed VP 7000 and IVAC 572). Transfus Med. 2007;17(4):290-5.

30. Lieshout-Krikke RW, Van der Meer PF, Koopman MMW, Korte DDE. Effect on the quality of blood components after simulated blood transfusions using volumetric infusion pumps. Transfusion. 2011;51(8):1835-9.

31. Cook DJ, Guyatt GH, Laupacis A, Sackett DL, Goldberg RJ. Clinical recommendations using levels of evidence for antithrombotic agents. Chest. 1995;108(4 Suppl):227S-30

32. Langhi Jr DM, Pereira JPM, Pereira CM. Reações Transfusionais Hemolíticas. In: Bordin JO, Langhi Jr DM, Covas DT. Hemoterapia: fundamentos e prática. São Paulo: Atheneu; 2007. p. 437-44.

33. Raza S, Baig Ma, Chang C, Dabas R, Akhtar M, Khan A. A Prospective Study on Red Blood Cell Transfusion Related Hyperkalemia in Critically Ill Patients. J Clin Med Res. 2015;7(6):417-21.

34. Vraets $A$, Lin Y, Callum J. Transfusion-Associated Hyperkalemia. Transfusion Med Rev. 2011;25(3):18496.

35. Smith HM, Farrow SJ, Ackerman JD, Stubbs JR, Sprung J. Cardiac Arrests Associated with Hyperkalemia During Red Blood Cell Transfusion: A Case Series. Anesth Analg. 2008;106(4):1062-9.

36. McClelland B. Guidelines for the Blood Transfusion Services in the United Kingdom. 7th ed. London: The Stationery Office; 2005.

37. Ministério da Saúde (BR). Agência Nacional de Vigilância Sanitária (ANVISA). RDC no 34, de 11 de junho de 2004. Dispõe sobre as boas práticas no ciclo do sangue. Brasília; 2014.

38. International Electrotechnical Commission (IEC). International Organization for Standardization (ISO) $n^{\circ}$
1135-4:2012: Transfusion equipment for medical use Part 4: Transfusion sets for single use, 2012.

39. Janatpour KA, Paglieroni TG, Crocker VL, Holland PV. Visual assessment of hemolysis in red blood cell units and segments can be deceptive. Transfusion. 2004;44(7):984-9.

40. Pedreira MLG, Peterlini MAS, Harada MJCS. Tecnologia da informação e prevenção de erros de medicação em pediatria: prescrição informatizada, código de barras e bombas de infusão inteligentes. Rev Soc Bras Enferm Ped. 2005;5(1):55-61.
Copyright $\odot 2016$ Revista Latino-Americana de Enfermagem This is an Open Access article distributed under the terms of the Creative Commons (CC BY).

This license lets others distribute, remix, tweak, and build upon your work, even commercially, as long as they credit you for the original creation. This is the most accommodating of licenses offered. Recommended for maximum dissemination and use of licensed materials. 